\title{
THE EFFECT OF CAPITAL STRUCTURE WHEN EXPECTED AGENCY COSTS ARE EXTREME
}

\author{
Campbell R. Harvey \\ Karl V. Lins \\ Andrew H. Roper \\ Working Paper 8452 \\ http://www.nber.org/papers/w8452
NATIONAL BUREAU OF ECONOMIC RESEARCH 1050 Massachusetts Avenue
Cambridge, MA 02138
September 2001

We wish to thank Ian Domowitz, Narayanan Jayaraman, John Graham, Mike Lemmon, and participants at the Second Annual CIFRA International Finance Conference at London Business School and the Seventh Annual Georgia Tech International Finance Conference for helpful comments and suggestions. The views expressed herein are those of the authors and not necessarily those of the National Bureau of Economic Research.

(C) 2001 by Campbell R. Harvey, Karl V. Lins and Andrew H. Roper. All rights reserved. Short sections of text, not to exceed two paragraphs, may be quoted without explicit permission provided that full credit, including (C) notice, is given to the source. 
The Effect of Capital Structure When Expected Agency Costs are Extreme Campbell R. Harvey, Karl V. Lins and Andrew H. Roper

NBER Working Paper No. 8452

September 2001

JEL No. G32, G30, G15, G21

\begin{abstract}
$\underline{\text { ABSTRACT }}$
We provide new evidence that debt creates shareholder value for firms that face agency costs. Our tests are unique in two respects. First, we focus on a sample of firms with potentially extreme agency problems. We study emerging market firms where the routine use of pyramid ownership structures provides an acute separation of management cash flow rights and control rights. Second, we argue that not all debt is the same. Using new data on global debt issuance, we find that the type of debt that positively impacts shareholder value is the type that closely monitors management. This combination of a sample of firms with extreme expected agency problems and detailed information on the different types of debt allows us to construct powerful tests of whether debt can mitigate the effects of agency and information problems. Among other results, we find that the abnormal returns resulting from syndicated term loans (which provide monitoring) are significantly related to the extent of the separation of ownership and control. Our results are consistent with the idea that debt creates value because it reduces the agency costs associated with overinvestment.
\end{abstract}

Campbell R. Harvey

Fuqua School of Business

Duke University

Box 90120

Durham, NC 27708

and NBER

cam.harvey@duke.edu
Karl V. Lins

David Eccles School of Business

University of Utah

1645 E. Campus Center Drive

Salt Lake City, UT 84112

finkvl@business.utah.edu
Andrew H. Roper

Fuqua School of Business

Duke University

Box 90120

Durham, NC 27708

ar10@mail.duke.edu 


\section{Introduction}

This paper investigates the extent to which debt capital creates value in firms suspected of having extreme agency problems. We focus on agency problems resulting from the separation of management control rights from the cash flow consequences of those rights (Jensen and Meckling (1976)). These problems are severe in emerging markets where managers and families routinely employ pyramid ownership structures and dominate the board of directors to lever their cash flow rights into greater control rights. Additionally, emerging markets generally suffer from a lack of shareholder and creditor protection and have poorly developed legal systems (La Porta, Lopez-de-Silanes, Shleifer, and Vishny (hereafter LLSV) (1998)) as well as underdeveloped markets for corporate control. Combined, these characteristics increase the potential for extreme agency problems resulting in increased costs associated with overinvestment or the outright diversion of corporate funds. ${ }^{1}$

Several papers have shown that the separation of control rights from cash flow rights via pyramid structures or, less frequently, non-voting equity is negatively related to firm value. $^{2}$ The international investment community is also aware of these shortcomings in emerging markets. For example, Mark Mobius (president of Templeton Emerging Markets Fund), has commented "corporate governance is not improving so why fight it? ... It's too

\footnotetext{
${ }^{1}$ In survey papers, Shleifer and Vishny (1997) and Stein (2001) note that investment distortions from agency and information problems are relatively mild in the U.S. and other countries with highly evolved legal, auditing, and contracting environments. In contrast, Johnson, La Porta, Lopez-de-Silanes, and Shleifer (2000) show that outright asset stripping (tunneling) by managers is common in European emerging markets.

${ }^{2}$ See Claessens, Djankov, Fan, and Lang (2001), La Porta, Lopez-de-Silanes, Shleifer and Vishny (2000) and Lins (2000), among others, for evidence on firms in emerging markets where formal control rights are often larger than cash flow rights as a result of pyramid ownership structures and family business groups. See Morck, Shleifer, and Vishny (1988) and McConnell and Servaes (1990), among others, for evidence on firms in the U.S. where formal control rights equal cash flow rights, yet informal control rights may be higher due to entrenchment.
} 
Herculean a task and it's too embedded in the culture." ${ }^{13}$ Similarly, the U.S.-based Association of Certified Fraud Examiners estimates that the agency costs of governance failures within Asia may be as high as 10\% of annual sales. ${ }^{4}$ In these environments, minority shareholders may welcome the increased disclosure or due-diligence and monitoring associated with capital from more developed markets.

When firms face potentially high agency costs, debt should create value if it directly reduces overinvestment as in Jensen (1986) or if it allows firms to signal that they do not or will not overinvest. O ur investigation uses a unique dataset constructed to specifically examine debt's ability to serve as an alternative governance mechanism when firms are expected to face extreme agency costs. We capture firm-level variation in expected agency costs by tracing out management and family group ownership of control rights and cash flow rights in emerging market firms and incorporating a proxy for the level of management's discretionary expenditures. Because the valuation impact of debt should be related to the type of contract offered, we incorporate several different types of debt. In particular, we collect firm-level international debt issuance activity from 1980 to 1997 from international and foreign bond markets as well as from the internationally-syndicated bank market. This combination of a sample of firms with extreme agency problems and detailed information on their different types of debt allows us to construct powerful tests of the agency hypothesis. To our knowledge, we are the first to undertake such a comprehensive empirical analysis of debt's impact on agency problems.

We find that book leverage, in particular short-term leverage, helps mitigate the loss in shareholder value attributed to the separation of ownership and control. Our analysis also suggests that international debt issues with more onerous reporting requirements or implicit

\footnotetext{
${ }^{3}$ Karmin, Craig. W all Street Journal (11/ 08/ 00).
} 
limitations on operating activity as a result of monitoring increase shareholder value. For example, we find positive cumulative abnormal returns of 1.9\% associated with initial public U.S. market bonds and international bonds and of $1.1 \%$ associated with the renewal process of syndicated term loans. The abnormal returns resulting from syndicated term loans are correlated with the extent of the separation of ownership and control. The gains and losses associated with other forms of debt contracts do not appear to be related to agency costs. O ur results suggest that monitored debt is indeed effective at mitigating agency problems associated with overinvestment [Jensen (1986)].

The paper is organized as follows. Section 2 summarizes the relationships between debt, value, and agency costs. Section 3 describes the sample construction and provides statistics on both our sample of firms and sample of debt issuance activity. Section 4 describes the regression and event study methodologies used to examine the relationship between debt capital, ownership structure, and firm value. Section 5 contains the results of our empirical tests. Some concluding remarks are offered in the final section.

\section{Debt, value and the separation of management ownership and control}

O ur focus on the relationship between debt, shareholder value, and agency costs begins with an assumption: in equilibrium there exists a "meaningful conflict" between outside shareholders and management that results from the separation of ownership and control [Jensen and Meckling (1976)]. In this agency setting, Jensen (1986, 1993), Stulz (1990), Hart and Moore (1995), and Zweibel (1996) suggest that debt servicing obligations help to discourage overinvestment of free cash flow. In equilibrium, firms may not on

\footnotetext{
${ }^{4}$ Bangk ok Post (6/ 4/ 01). Within the U.S., these costs are estimated to be as high as $6 \%$ of annual sales.
} 
average overinvest because capital structure can potentially counterbalance managerial agency costs with the governance provided by debt payments [Stein (2001)].

When there exists a sufficient proportion of firms facing managerial agency costs, even well-intentioned managers may rely on capital structure to increase shareholder value. Leland and Pyle (1977) and Ross (1977) demonstrate how firms may vary their financial structure to signal their quality. In this setting, high quality managers acting on behalf of shareholders find themselves more willing to incur higher costs associated with debt finance in order to separate themselves in equilibrium from low quality self-interested managers. Further, as in Titman and Trueman (1986), firms may choose to obtain debt from high quality outsiders, such as international banks, to signal investors about the firm's quality.

Whether debt curtails overinvestment by absorbing excess cash flows or debt allows managers to signal their quality, it is the presence of expected managerial agency costs that allows certain types of debt to create value for outside shareholders. In the former case, short-term debt may be especially suited since it forces managers to "disgorge funds they might otherwise use to make unprofitable but empire building investments." ${ }^{5}$ Moreover, short-term debt also allows creditors to trigger bankruptcy when the firm's assets may be more productively employed elsewhere. In the latter case, Flannery (1986) argues that high quality firms will choose more costly borrowing strategies, such as rolling over short-term debt, that cause low quality firms to select out. D iamond (1991a) suggests that firms temper their use of short-term debt in order to balance the cost of liquidity risk against the gains achieved from signaling with short-term debt.

However, in emerging markets it is not uncommon for interlinked family groups to control both a firm and a bank. When debt capital is acquired through such 'relationship' 
banking or through a common business group, the additional liquidity may simply add to the overinvestment problem. The presence of 'relationship' lending also means that domestic debt contracts, even short term ones, may not provide effective signaling for emerging market firms. For example, in reference to Korean banking practices, Standard and Poor's found that "domestic lenders are deluding themselves ... if they think that keeping most debt maturities relatively short - less than three years - is a substitute for proper credit analysis." ${ }^{\prime 6}$ Without proper credit analysis, there can be no guarantee that the relative pricing of domestic short-term and long-term debt will allow firms to signal their quality.

When domestic debt markets fail to mitigate managerial agency costs, international debt markets may provide unique alternative mechanisms for corporate governance. For example, several authors have suggested that certification and reputation are key influences in the international security issuance decision [see Foerster and Karolyi (1999), Miller (1999), and Miller and Puthenpurackal (2001)]. However, when expected agency costs are sufficiently widespread, Diamond (1991b) suggests that borrowers may be forced to subject themselves to being monitored as well. When international lenders can commit to monitoring, firms may acquire high quality reputations by selecting into this market. Here the valuation effect for shareholders is similar to the certification effect. On the other hand, if credit rationing occurs in local debt markets, certain firms may be left with no alternative but to borrow in monitored international debt markets. In this scenario, minority shareholders should benefit from a change in management's investment behavior that results from the threat or act of monitoring. In sum, minority shareholders should benefit from intensively monitored debt in a setting where managers are likely to exploit them and where

\footnotetext{
${ }^{5}$ See page 568 of Hart and Moore (1995). For an empirical study of short-term debt for U.S. firms see Barclay and Smith (1995).

${ }^{6}$ A sia Pulse (06/04/ 01).
} 
information asymmetry is severe enough that they cannot reasonably infer what managers are doing with a firm's funds.

The capital structure literature provides evidence that certain forms of debt issuance directly or indirectly create value for firms [see, among others, Mikkelson and Partch (1986), Kim and Stulz (1988), James (1988), Lummer and McConnell (1989), Chaplinski and Ramchand (2000), and Miller and Puthenpurackal (2001)]. However, much remains to be learned about what specific types of debt create value and whether the value created by debt is related to managerial agency costs. McConnell and Servaes (1995) investigate the latter question and find that book leverage is positively correlated with firm value when investment opportunities are scarce, indicating that debt does provide governance. However, the root of the agency problem is the separation of ownership and control and not the investment opportunity set. They do not directly test whether debt matters more when managerial incentives are misaligned, nor do they investigate what type of debt creates value.

To develop powerful tests that debt lessens the impact of agency problems requires significant heterogeneity in both debt contracts and the extent of agency problems resulting from the separation of cash flow rights from control rights. O ur paper exploits this heterogeneity in its construction of three sets of tests to uncover debt's impact on value. The first set of tests explores cross-sectional variation in firm value and the impact of book leverage on agency costs associated with managerial ownership and overinvestment. The second set of tests measures the impact on shareholder value of incremental debt offerings using traditional event study techniques. These tests allow us to isolate the effect of an incremental leverage decision on shareholder valuation from the cumulative effect of past leverage decisions on shareholder valuation. Moreover, our incremental international debt issuance data includes contracts from various debt capital markets. This heterogeneity allows 
us to isolate the types of debt contracts expected to create value by alleviating expected agency costs. O ur final set of tests explores why debt issues lead to valuation effects. We estimate regressions to see if firm size, leverage, discretionary expenditures, and managerial ownership may explain the cross-sectional variation in abnormal returns.

\section{Data}

\subsection{Sample selection}

O ur 'potential sample' of emerging market firms includes all exchange-listed nonfinancial companies covered by Worldscope from 1990 to 1997. From this 'potential sample' of 1706 firms from 24 emerging markets, we are able to trace out the ultimate ownership structure for 1132 firms from 18 emerging markets: Argentina, Brazil, Chile, the Czech Republic, Hong Kong, Indonesia, Israel, Malaysia, Peru, the Philippines, Portugal, Singapore, South Africa, South Korea, Sri Lanka, Taiwan, Thailand, and Turkey. These firms comprise our 'ownership sample.'

O ur measure of the degree of separation of managerial ownership and control employs a variable compiled in Lins (2000). The measure, 'cash flow rights leverage', is computed as the ratio of the management group's control rights to its cash flow rights. Control rights and cash flow rights are measured for the 1995/ 1996 period and incorporate both direct and indirect holdings of a firm's top managers and their family members. Indirect holdings refer to pyramid structures in which control rights to Firm A (i.e. the sample firm) are held through Firm B or Nominee Account B which has a stake in Firm A (i.e. the sample firm's blockholders). ${ }^{7}$ Cash flow rights held by management will be lower

\footnotetext{
${ }^{7}$ The management group of Firm A is deemed to have indirect control via Firm B (or Nominee Account B) if one or more managers or their families has an equity blockholding in Firm B or is a top manager of Firm B.
} 
than control rights when indirect stakes with less than full ownership or shares with superior voting rights are used in a firm's ownership structure. ${ }^{8}$ Values for cash flow rights leverage are truncated at the 95th percentile (a value of about 10) to alleviate problems with outliers.

We next collect firm-level data from 1980 to 1997 on debt issues in domestic, foreign, and international bond markets using SD C's G lobal New Issue D atabase and in the international syndicated bank market using Capital D ata's Loanware database. We are able to obtain a debt issuance record using these sources for 896 firms; these constitute our 'issuance sample.' 0 ur issuance record tracks debt issuance activity in the following markets: foreign bond markets (e.g. Samurai and Yankee bonds); Eurobond markets; internationally-syndicated bank issues such as term loans, revolving credits, Euro commercial paper programs, and Euro CD programs; and domestic public and private bond markets. ${ }^{10}$ The issuing record is not comprehensive for the markets we consider; for instance, we lack issuance information from domestic banks. Nevertheless, the issuance data are broadly representative of the types of debt capital available to firms from emerging markets.

By incorporating debt issues from domestic and international markets, we introduce significant variation in terms of disclosure requirements, creditor rights, enforceability of creditor rights, the creditor base, and covenants or monitoring. Figure 1 summarizes key differences in these attributes across the international debt markets in our sample. We focus

\footnotetext{
Also, firms are removed from the sample if more than 10 percent of the cash flow rights of the firm's direct blockholders cannot be observed.

${ }^{8}$ For example, if Firm B owns 50 percent of Firm A and the management group of Firm A owns 50 percent of Firm B then the management group's control rights for Firm A equal 50 percent while their cash flow rights equal 25 percent. Cash flow leverage in this example equals two.

9 We require both the issue signing date and the principal amount of the contract to be identified in order to be included in a firm's issuance record. Countries in the issuance sample closely track those in the ownership sample except that the issuing sample includes Mexico and Venezuela and does not include Sri Lanka. 10 The domestic bond coverage is limited to Argentina, Brazil, the Czech Republic, Indonesia, Malaysia, Mexico, Peru, Portugal, Singapore, Thailand and Venezuela from 1991 to 1997 and South Korea from 1994 to 1997.
} 
the discussion in terms of the varying degrees of financial disclosure requirements and monitoring mechanisms and incentives.

A firm's willingness to adhere to strict financial disclosure requirements may provide certification that helps to alleviate agency costs associated with asymmetric information [Titman and Trueman (1986)]. However, not all markets require the same level of disclosure. For example, publicly-placed Eurobonds do not require additional disclosure outside the normal reporting requirements of the local country. First time issuers of Eurobonds that list on the London Stock Exchange are only required to file two years of independently audited income and balance sheet statements in English which may or may not comply with internationally accepted accounting standards. ${ }^{11}$ At the other end of the spectrum, publicly-placed U.S. market foreign bonds fall under the consideration of the U.S. Securities Act of 1933. The firms must report timely financial statements that adhere to GAAP as well as meet stringent registration requirements. D espite substantially different disclosure requirements, an advantage of both markets is that they may allow emerging market firms to enlarge their overall investor base, which could positively affect value [Merton (1987)].

O ur sample of international debt markets also includes significant heterogeneity in terms of monitoring potential. Creditors may willingly commit to incur the cost of monitoring provided (1) the costs of monitoring are not duplicated by multiple monitors, (2) mechanisms (such as covenants) exists to facilitate monitoring, and (3) creditors can effectively use the legal system in the event that monitoring suggests a covenant violation. Diamond (1984) suggests that creditors cannot credibly commit to monitoring unless the creditor base is sufficiently concentrated to avoid duplicating monitoring costs. The diffuse 
creditor base of public debt markets is not likely to meet this criterion. Privately-placed debt, on the other hand, is typically owned and traded by small numbers of institutional investors. As Chaplinsky and Ramchand (2000) suggest, this clientele of creditors may be better equipped to infer quality or monitor these contracts, particularly in the U.S. foreign debt market where covenants are present. The creditor base is even more concentrated in intemationally syndicated bank agreements where, according to Howcroft and Solomon (1985), the lead manager in internationally-syndicated bank agreements faces a fiduciary duty to monitor the firm and inform syndicate members when the firm is in technical default. Moreover, given that most syndicated agreements are governed by New Y ork State law (Howcroft and Solomon (1985)), this form of international debt contract may be the most able to credibly commit to monitoring.

Thus, we suspect that internationally-syndicated bank instruments will provide the discipline and information usually associated with financial intermediaries in more developed markets. Term loans, rather than credit agreements, may be the best instrument for this since proceeds are disbursed up front and violations of covenants allow the bank group to place the firm in default. ${ }^{12}$ To the extent that syndicated term loans are publicized, a firm may also obtain increased external visibility from issuing in this market. Finally, we expect that shareholders will benefit from subsequent rounds of refinancing as bank managers certify compliance on behalf of firm management according to the clauses present in the current term loan contract.

11 See L isting Requirements of the U K L isting A uthority - E urobonds available at http:/ / www.londonstockexchange.com/ international/ pack_description.asp.

12 In contrast, a credit commitment often does not directly pass a bank's funds on to the borrowing firm rather, the firm obtains only a promise that funds will be lent upon request, subject to covenants being met at that time. 


\subsection{Summary statistics}

Table 1 contains descriptive statistics for the potential sample of firms as well as for our subsamples used in subsequent tests. The first column provides firm-level averages for key financial variables for the potential sample. The table shows a basic leverage ratio of debt to assets of 0.30, which is lower than that found by Booth, Aivazian, D emirguc-Kunt, and Maksimovic (2001) for ten developing economies during the 1980s, a period that includes some Latin American debt crisis years. It is, however, broadly consistent with the values found for this measure by Rajan and Zingales (1995) for firms from the U.S. and other developed countries. Short-term debt to total debt ratios average about 0.55, a level which is comparable to the short-term debt ratios of most developing countries in Booth, Aivazian, D emirguc-Kunt, and Maksimovic, and which is higher than the short-term debt ratios of the developed countries from Rajan and Zingales. O ur short-term debt statistic supports the findings of D emirguc-Kunt and Maksimovic (1999) that firms from developing countries have substantially lower amounts of long-term debt.

Table 1 shows that mean cash flow rights leverage for the ownership sample is 2.09, implying that the average management group across these emerging markets is able to turn one cash flow right into more than two control rights. However, the median firm has no cash flow rights leverage (a value of one), indicating that some firms make extensive use of mechanisms that uncouple management cash flow rights from their control rights, while others do not. Other statistics in the ownership sample are comparable to those in the potential sample of firms.

The third column of Table 1 displays characteristics of our issuing sample. On average, these firms are larger and more levered than both the potential sample and the ownership sample. They also have a lower proportion of short-term debt to total debt. If 
larger and more recognizable emerging market firms are better able to tap the public and international debt markets, this could account for these summary statistic differences between the issuing sample and the other samples.

Many of our tests require firms to have both an identified ownership structure and a debt issuance record. The final column of Table 1 reports summary statistics for this 'ownership issuance sample.' When compared to the ownership sample of 1132 firms, the 387 firms that also issued debt are larger, have higher total debt levels, and lower short-term debt ratios. These differences are significant at the one-percent level.

Table 2 describes the issuance record of our sample firms. Panel A demonstrates that firms that go outside their borders for debt financing borrow in larger increments at longer maturities than do domestic debt issuers. The table also shows that foreign bond issues are large and longer-dated than internationally-syndicated bank issues. ${ }^{13}$ Consistent with our expectations, Panel A shows that it is the largest firms that are able to tap the international bond markets, a result consistent with Cantillo and Wright (2000).

Panels B and C of Table 2 highlight issue frequency and issue proceeds by year and marketplace for the period 1990-1997. We tabulate only these years for brevity's sake because they constitute the vast majority of the issuance activity reported by our data sources. Over the 1990-1997 period, internationally-syndicated issues constitute the largest proportion of issues (64\%) and total issuance volume (59\%) of the various debt instruments. For each year, syndicated term loans comprise at least 36\% of total debt issue proceeds (maximum of 55\%), far exceeding the other forms of debt capital that we study. This finding that syndicated issues constitute the primary source for extra-national financing for

\footnotetext{
${ }^{13} \mathrm{O}$ ur data sources document very few non-U.S. foreign bond issues (e.g. Samurai bonds). We exclude these issues from our analysis because tests with this small subset would lack power and because reporting and
} 
firms from emerging markets is consistent with evidence presented by D omowitz, Glen, and Madhavan (2000). D espite its relative importance, the internationally-syndicated banking market has been largely ignored in previous capital structure studies.

\section{Methodology}

We employ two proxies for value in our tests. O ur proxy for firm value in the crosssectional regressions, Tobin's $Q$, is computed as the market value of equity plus the book value of assets less the book value of equity in the numerator and the book value of assets in the denominator. We measure Tobin's Q using accounting data predominantly from fiscal year-end 1996 and winsorize this variable at the 1st and 99th percentiles to alleviate problems associated with outliers.

In our issuance sample, we measure shareholder value as the cumulative abnormal return from traditional event study techniques. We collect daily local-currency return data (where possible) from the security price database provided in FACTSET. ${ }^{14}$ Requiring daily security price data reduces the number of firms used in the event study to 514 firms. We estimate a market model with Scholes-Williams (1977) betas over an estimation window beginning 120 trading days before and ending 20 trading days before the issue date..$^{15} \mathrm{We}$ proxy for a country's market return using the Morgan Stanley market-capitalization weighted indices. Average cumulative abnormal returns (CARs) are reported for a six-day event

disclosure characteristics of these foreign issue markets are not comparable to those for U.S.-issued foreign bonds.

14 Most firms in our sample have multiple share classes outstanding; as such, we select the particular share class that Worldscope considers to be the most liquid and widely held by outside investors.

${ }_{15}$ Mikkelson and Partch (1986), James (1987), Lummer and McConnell (1989) and Miller (1999) use a simple market model to proxy for the normal return process. We estimate Scholes-Williams (1977) betas in order to control for the bias that may result from non-synchronous trading in emerging markets. 
window that includes one day prior to issue, the issue date, and four subsequent trading days.

We use the issue date of the debt financing agreement as the event date, rather than an announcement date, due to our inability to obtain meaningful announcement dates for debt contracts other than intemational bond offerings. ${ }^{16}$ However, our use of the issue date may not be problematic when it comes to interpreting our results. If there is uncertainty at the announcement date as to whether the financing will actually be completed, then measuring an announcement effect will not fully reflect the benefit (if any) of a completed debt contract. Mikkelson and Partch (1986) demonstrate that for U.S. firms it is important to study the valuation effect of completed contracts.

The variables of interest used to explain the relationship between debt and value are cash flow rights leverage (described previously) and the type of leverage. Leverage can be defined as overall book leverage (ratio of total debt to assets), short-term leverage (ratio of short-term debt to assets), or long-term leverage (ratio of long-term debt to assets). In our issuance sample, leverage is classified according to the marketplace of issue and relative timing of issue. Conditional on a given degree of separation of ownership and control, higher leverage should increase value if debt revolves agency problems. Furthermore, conditional on a given degree of separation, the valuation impact of debt may be related to the type of debt issued. In both cases, we can look at the coefficient on cash flow rights leverage to assess the ability of debt to mitigate agency costs.

To help ensure that the effects attributed to ownership and capital structure are not caused by other factors, we incorporate controls for size and the ratio of capital expenditures

\footnotetext{
${ }^{16}$ James (1987) and Lummer and McConnell (1989) obtain announcement dates for bank lending agreements from the $W$ all Street Journal Index. Unfortunately, this source does not consistently include financing agreements for firms from emerging markets.
} 
to total assets in the regressions. Size is measured as the log of total assets converted to U.S. dollars and may proxy for asymmetric information. The ratio of capital expenditures to total assets has two interpretations. If the ratio proxies for expected growth opportunities, we would expect debt to be negatively related to firm value for firms with high capital expenditures. However, if managers routinely overinvest, high levels of capital expenditures may indicate inefficient investment choices. ${ }^{17}$ In this agency setting, debt issues would be positively correlated with capital expenditures. This interpretation leads us to describe the ratio of capital expenditures to assets as discretionary expenditures. Finally, we include country and industry dummies (fixed effects) in regressions involving Tobin's $Q$ to help account for unobserved heterogeneity.

The cross-sectional regressions are designed to explain the variation in firm value that can be attributed to variation across firms' ownership structures and capital structures. While cross-sectional regressions measure the average valuation impact across firms with similar characteristics, we are also interested in the marginal impact of debt issuance. Traditional event study analysis provides an excellent medium to test the marginal impact of incremental financing decisions on shareholder value.

Using the cumulative abnormal returns from our event study, we conduct univariate and multivariate cross-sectional analyses to help explain the variation in abnormal returns. Both analyses use a GLS regression framework that incorporates the issue market heterogeneity across contracts. In our multivariate analysis, we model the relationships between CARs and firm-level attributes using fixed effects and variable slope coefficients in which we allow the effect of cash flow rights leverage and discretionary expenditures on abnormal returns to vary across different debt contracts.

\footnotetext{
${ }^{17}$ Harvey and Roper (1999) and Pomerleano (1999) document low levels of return on invested capital in East
} 


\section{Results}

\subsection{Cross-sectional analysis of ownership sample}

A direct test of debt's ability to mitigate agency costs requires a measurement of the valuation impact of debt conditional on the level of ownership separation. In our regressions, an interaction term between cash flow rights leverage and debt measures this conditional effect. Table 3 reports regression models with ownership and leverage variables as well as controls. The unconditional coefficient on cash flow rights leverage of -0.048 reported in Model (1) confirms evidence reported in Lins (2000) that a firm's degree of separation between managerial control rights and cash flow rights is negatively related to firm value. The coefficient indicates that decreasing cash flow rights leverage from 2 to 1 increases a firm's Q value by 0.048. A management group could potentially effect this change by selling its interest in an indirect holding and using these proceeds to purchase shares directly.

More important for our analysis, the coefficient of 0.094 on the interaction between cash flow rights leverage and debt suggests that debt plays a positive role in alleviating agency problems. However, the coefficient value is not large enough to overcome the negative unconditional effect of debt found in the regression. ${ }^{18}$ But, if certain types of debt alleviate agency costs while others simply add financial risk or exacerbate agency problems, we would expect this conflicting result. As a robustness check, we partition our sample into firms with above- and below-median levels of debt and re-estimate the first model. In the

\footnotetext{
Asia during our sample period.

${ }^{18}$ The overall economic effect of a change in leverage from the $25^{\text {th }}$ percentile $(0.11)$ to the $75^{\text {th }}$ percentile (0.41) for a firm with the mean cash flow rights leverage of 2.09 is as follows: the positive interaction term effect, $0.094 \times 2.09 \times(0.41-0.11)=0.059$, is added to the negative unconditional debt effect, $-1.072 \times(0.41-$ $0.11)=-0.322$, for a net change in Tobin's $Q$ of -0.263 .
} 
high debt sub-sample, there is no negative effect of cash flow rights leverage on value, which could again indicate that debt has helped to mitigate agency problems (results not reported).

To investigate whether heterogeneity in book leverage can help explain how debt creates value, Model (2) includes both short-term and long-term debt ratios separately as well as their interactions with the ownership separation variable, cash flow rights leverage. The interaction term between cash flow rights leverage and short-term debt alone accounts for the significant effect of debt capital in mitigating the value loss attributed to ownership separation. However, the large negative unconditional effect of short-term leverage once again overwhelms its conditional positive impact. ${ }^{19}$ As suggested previously, this could be because not all short-term debt contracts create value, particularly those issued by domestic lenders with strong ties to a firm.

We next split the ownership sample into firms with above- and below-median levels of capital expenditures to see whether the ability of debt to alleviate the value loss associated with the separation of ownership and control is related to the potential for overinvestment. Consistent with the interpretation that high levels of capital expenditures represent an agency problem, the interaction terms between debt and ownership separation from Models (3) and (5) are positive and significant only among firms with high capital expenditure ratios. Similarly, Models (4) and (6) show that the interaction between short-term debt and ownership separation is positively related to firm value only in high-spending firms.

\footnotetext{
${ }^{19}$ The regression coefficients indicate that a firm with cash flow rights leverage of 2.09 that moved its shortterm debt ratio from the $25^{\text {th }}$ percentile $(0.04)$ to the $75^{\text {th }}$ percentile $(0.24)$ would have a net change in Tobin's Q of -0.177 .
} 


\subsection{Issuanœ versus ownership sample}

Before moving into issue-level tests, we want to explore whether the relation between ownership structure, book leverage, and firm value in the ownership issuance sample is different than that for the ownership non-issuance sample. Because the average firm in the ownership issuance sample is larger, more levered, and has a significantly longer debt maturity structure than a firm in the ownership sample (see Table 1), we may expect the impact of size and leverage to dominate in this sub-sample. These effects may overwhelm any effect attributed to cash flow rights leverage or the interaction of cash flow rights leverage and financial leverage.

The first columns of Table 4 report parameter estimates for our basic regressions estimated on the smaller ownership issuance sample. The coefficients on cash flow rights leverage and the interaction between cash flow rights leverage and debt in Models (1) and (2) are not significant at standard reporting levels. Thus, it may be the case that these issuing firms have resolved agency tensions by successfully contracting in an environment which forces management to act in the best interest of outside shareholders. On the other hand, the ownership issuance sample may simply lack sufficient power to detect the effect of cash flow rights leverage. To test this, we re-estimate our two basic models using the ownership non-issuance sample. While the coefficients on cash flow rights leverage and the interactions with debt are significant, tests under the null that these coefficients are different across the two samples are rejected. Hence, we suspect that the insignificant effect of cash flow rights leverage and its interaction with debt in the ownership issuance sample results from a lack of power. 


\subsection{Inoorporating the heterogeneity in debt contracts across issue mark ets}

In this section, we test whether debt issues create value for outside shareholders. We investigate the variation in abnormal returns associated with the heterogeneity among debt contracts issued in different markets in Table $5 .^{20}$ The table shows that internationallysyndicated term loans account for all of the positive abnormal returns associated with debt issues. The issuance of syndicated term loans leads to a 1.34\% average abnormal return which is significant at the $1 \%$ level. Moreover, the proportion of abnormal returns that are positive (56\%) is also significant at the $1 \%$ level. This finding is consistent with the evidence on bank loans for U.S. firms provided by James (1987) and Lummer and McConnell (1989). Eurobonds and domestic bonds do not appear to enhance shareholder value. This finding is not consistent with evidence reported by Kim and Stulz (1988) for U.S. firms. ${ }^{21}$ Finally, Yankee bonds and bonds issued under Rule 144A also do not appear to lead to shareholder gains. This evidence is inconsistent with Miller and Puthenpurackal (2001), who examine primarily Canadian and European firms, and with Chaplinski and Ramchand (2000).

\subsection{Incorporating heterogeneity in the sequencing of debt contracts}

The preceding analysis averages the effects of multiple issues by firms. Another source of debt heterogeneity implicit in our issuance sample is the firm-specific sequencing of issues across and within various markets. If international capital markets provide some form of certification, either through increased disclosure or formal listing requirements, then we may expect the gains to shareholders to be limited to the initial offering. Subsequent

\footnotetext{
20 The availability of daily security price data limits our event study to 1500 issues. However, a firm's issuance record incorporates all identified debt issues regardless of whether these issues can be used in subsequent analysis.
} 
offerings are not likely to improve certification, so they may not lead to increases in shareholder value. On the other hand, if successful re-contracting in monitored debt markets allows firms to earn better reputations as suggested by Diamond (1991b), then we expect shareholders to gain from subsequent issues.

Table 6 partitions the average CARs associated with international debt offerings into two panels. Panel A provides abnormal returns associated with the firm-specific initial offering in international debt markets. We next look at the effect of issue timing based on whether or not a firm has already issued debt in a particular market. For firms that issue in the same market more than once, we collect all subsequent (secondary) offerings in Panel B.

Panel A shows that the largest number of firms (182) initially raised debt in international debt capital markets through the syndicated term loan market. Only 71 firms raised their first international debt capital by offering public Eurobonds or Y ankee bonds. Panel A also shows that firms introduced to international creditors through public offerings in either the Eurobond or Y ankee bond market experience an average CAR of 0.92\%. This return is significant at the $10 \%$ level. While the individual sample sizes may constrain our ability to find significant CARs in separate categories for initial public Eurobond or Yankee bond markets, both markets appear to reward investors with positive average abnormal returns. The right hand columns of Panel A report the difference between the average CAR for subsequent international issues and the average CAR for initial international issues. The difference in average CARs between initial and subsequent foreign and international bond offerings, $2.7 \%$, is highly significant. ${ }^{22}$

\footnotetext{
${ }^{21}$ We have no reason to expect the gains to shareholders of U.S. corporations to be similar to the gains to shareholders in emerging markets. Shareholders in U.S. corporations benefit from higher levels of shareholder protection and more developed forms of external governance.

22 The difference between initial and subsequent offerings reported in Panel A is computed as the GLS coefficient in a regression of the CARs on an intercept and a dummy variable that equals one if the particular
} 
We do not find that firms whose initial international issue is a private foreign or international bond placement reap shareholder gains. One reason for this may be that these markets have more liberal reporting requirements and may not be able to effectively certify firms. Moreover, while the creditors in these markets tend to be sophisticated qualified institutions that may be effective at monitoring, subsequent offerings do not lead to significant positive average abnormal returns (not tabled). The creditor base may be too diverse to credibly commit to perform valuable monitoring services, as suggested by Diamond (1984).

The negative and significant average abnormal return performance of $-0.81 \%$ for initial syndicated term loans is puzzling. While we might expect that syndicated credit agreements add value by producing information over time, we cannot explain why these same agreements destroy value initially.

Panel B summarizes the average abnormal returns associated with subsequent (secondary) security offerings across our sample of debt markets. This sub-sample includes 483 syndicated term loan issues, 136 public Eurobond and Yankee bond issues, and 46 privately placed Eurobond and U.S. Rule 144A issues. We find that the abnormal returns attributed to syndicated term loans result from secondary offerings. Subsequent syndicated term loan offerings lead to a 1.1\% average CAR over the 6-day abnormal window. Over $60 \%$ of these abnormal returns are positive. The right hand columns of Panel B report the difference between the average CAR for all subsequent issues in a particular debt market and the average CAR for a firm's initial issue. We find that the difference in average CARs between initial and subsequent syndicated term loans, $1.1 \%$, is significant at the $1 \%$ level. This finding is consistent with the U.S. firm results of Lummer and McConnell (1989).

issue is a subsequent issue. Each regression pools the CARs by market place of issue and uses weights defined 


\subsection{U nivariate cross-sectional analysis of C A Rs}

We begin our investigation into the determinants of the CARs documented in the previous sections with a univariate analysis. Table 7 provides CARs for debt categories based upon two types of sample splits. First, we sort our issuing sample into above- and below-median firm attributes where medians are based upon all firms in the ownership sample to better capture firm-level heterogeneity. ${ }^{23}$ We then report the results for initial public U.S. bond and Eurobond offerings as well as for subsequent internationallysyndicated term loans. In the right hand columns of Table 7, we report G LS regressions of the above-median attribute-specific indicator variable on the CARs for a debt category.

Panel A explores the relationships between average CARs and firm-level attributes for initial public U.S. market bond and Eurobond offerings. The panel suggests that most of the significance attributed to these offerings is concentrated in sub-samples of firm that are larger, less levered, have higher ratios of capital expenditures to assets, and have less shortterm leverage than the median firm. The regression-based tests reported in columns (6) and (7) indicate that the cross-sectional variation in CARs can be partially explained by differences in firm size, capital expenditures, and the amount of short-term leverage. We do not find any difference in average abnormal returns for initial public foreign and Eurobonds across the high and low cash flow rights leverage sub-samples. Both high and low cash flow rights leverage firms experience insignificant average CARs.

\footnotetext{
as the inverse of the variance of the market model residual for the firm issuing the debt security.

23 We partition the samples according to whether the firm's time series average of a particular attribute is above or below the median firm's time-series average of that attribute. We use the time-series average as opposed to the value of the attribute in the year of the issue or year before the issue because Worldscope's panel of fundamental data is limited in depth in terms of history. We investigate the robustness of our results on subsamples of issues from firms that have fundamental information in the year prior to the issue and find that our results are qualitatively similar. We also examine partitioning the sample according to country-specific medians. Once again, our results are qualitatively similar.
} 
Panel B suggests that the CARs associated with subsequent syndicated term loans are confined to the sub-samples of firms that are larger, more levered, and have higher capital spending ratios and lower short-term debt ratios than the median firm. Shareholders gain from subsequent term loan offerings regardless of whether management leverages it cash flow rights into higher control rights. However, shareholders of firms with high levels of cash flow rights leverage benefit more. The difference in CARs between sub-samples, $0.15 \%$, is significant at the $1 \%$ level.

O ur results indicate some sort of size effect since shareholders of large firms experience larger abnormal returns than shareholders of small firms for both initial public U.S. bonds and international bonds and subsequent term loans. The increased financial disclosure required in public debt markets or the information created through successful recontracting with syndicate banks may help to reduce the costs borne by outside shareholders that do not know what managers are doing with a firm's available resources.

We also find that the abnormal returns appear to be concentrated in the high capital expenditures to assets sub-sample, which again suggests that this measure may proxy for the tendency of management to overinvest. The data suggests that shareholders of firms with high ratios of capital expenditures to assets benefit from initial public foreign and international bond offerings and subsequent syndicated term loans.

There is an interesting asymmetry in the relationship between CARs and leverage across the two panels. The ability of initial issues in public U.S. bond markets and Eurobond markets to create value appears confined to the low leverage sub-sample. The value gain attributed to subsequent term loans, on the other hand, is concentrated in the high leverage subsample. If high levels of leverage proxy for a high risk of bankruptcy, our results suggest that only intensively monitored debt that contains restrictive covenants helps 
to create value. Moreover, this result provides an interesting contrast to our cross-sectional regression involving Tobin's $Q$. In these previous regressions, high levels of debt negated the marginal impact of debt to mitigate agency costs because the large negative unconditional coefficient on debt dominated the smaller positive coefficient on the interaction between debt and cash flow rights leverage. The results from our event study suggest that even highly levered firms may still benefit at the margin by adding leverage, provided the incremental debt is accompanied by monitoring.

\subsection{M ultivariate cross-sectional analysis of CA Rs}

O ur univariate analysis of cash flow rights leverage and discretionary expenditures suggests that the value created by certain types of debt may be related to information or agency costs. We next conduct a multivariate cross-sectional analysis in order to simultaneously examine the influence of multiple firm attributes on value created by debt issues.

Table 8 presents a basic regression model in which CARs are regressed on size, capital expenditure ratios, leverage ratios, and cash flow rights leverage. We estimate this model for eight debt issuance sub-categories which feature splits between initial and subsequent offerings across categories of debt. The table shows an interesting asymmetry in debt's impact to control agency costs across our two primary sub-samples: initial public U.S. bonds and Eurobonds and subsequent internationally-syndicated term loans. The value created by subsequent internationally-syndicated term loans is positively related to the extent of management separation of ownership and control, consistent with our previous results. On the other hand, the value created by initial public foreign and Eurobond offerings is negatively related to this separation. Also, the table shows that cash flow rights leverage is 
positively related to the CARs of initial syndicated term loan issues, which provides some evidence that investors value the potential monitoring that will take place under these contracts. This contrasts with the negative univariate CARs in Table 6 when this type of debt issue is a firm's first international issue.

In unreported regression models, we investigate whether our results may be attributed to systematic as well as firm-level governance by including a variable called 'rule of law' (LLSV (1998)) that characterizes the effectiveness of external corporate governance via the legal system. The positive effect of cash flow rights leverage in the subsequent syndicated term loan sample remains, although it is significant at only the $10 \%$ level. The coefficients on rule of law for the initial public U.S. bond and Eurobond sample and the subsequent syndicated term loans sample are insignificant. However, their sign is consistent with the hypothesis that shareholder benefit by contracting in more effective legal regimes outside their borders.

While Table 8 suggests that initial public foreign and Eurobonds do not create value by helping to mitigate agency costs, we should be cautious in making this inference. The subsample of initial public foreign and Eurobonds may simply lack the power to detect the true relationship between agency costs and the value of debt. In order to increase the power of our tests, we pool the estimated cumulative abnormal returns across our four debt categories and incorporate both initial and subsequent issue counters. We then use fixed effects and variable coefficients to test whether the CARs are related to the heterogeneity of the debt issues as a result of differences in market place of issue and the sequencing of each issue.

Specifically, we construct a model in which each issue-specific cumulative abnormal return is regressed on fixed effects that span the set of the issue's market and timing and the 
firm's country of domicile, as well as other firm-specific attributes. This means that for each issue we have four potential markets (international bonds grouped as public or private, syndicated term loans, and syndicated credit facilities), two potential issue timing counters (initial or subsequent issue of this type of debt), and 18 potential countries of domicile for the firm. This gives us 144 potential fixed effects in the model, although the actual number is much smaller as not all debt issue subsets occur in all countries. We allow our firmspecific slope coefficients on size, leverage, capital expenditure ratios, and cash flow rights leverage to vary across debt markets and issue timing, so there are eight possible slope coefficients for each of these firm attributes.

Based upon analyses that are not tabulated, we find that this model is rejected in favor of a restricted model that incorporates fixed effects for issue market, issue timing, and the firm's country of domicile, as well as separate slope coefficients for both capital expenditures and cash flow rights leverage. The model suggests parallel slopes for both size and leverage. ${ }^{24}$ Therefore, our first reported model in Table 9 has CARs regressed on: fixed effects for issue market, timing, and firm country of domicile (coefficients not reported); firm size; firm leverage; and capital expenditure and cash flow rights leverage slopes that vary across debt market and issue type.

The evidence from Model (1) in Table 9 is consistent with our previous results on subsequent syndicated term loans. The model shows that the value created by subsequent syndicated term loan issues remains related to cash flow rights leverage. The coefficient of $0.002(0.2 \%)$ indicates that, compared to the median firm with no cash flow rights leverage (a value of one), shareholders in a firm which has cash flow rights leverage at the $90^{\text {th }}$ percentile (a value of six) obtain excess returns that are one percentage point larger when the 
firm issues a subsequent internationally-syndicated term loan. The model also suggests that the cross-sectional variation in cumulative abnormal returns associated with other types of debt are not related to our agency cost proxy.

Model (2) in Table 9 incorporates a separate source of non-linearity in the cash flow rights leverage slope coefficients. As before, we allow each market and issue timing category to have a specific cash flow rights leverage coefficient and we now allow this coefficient to take on separate values across firms with low and high levels of capital expenditures. For the sake of brevity, we report only the coefficients on the high and low capital expenditure dummy variable interactions with cash flow rights leverage. As before, we expect that monitored debt should affect value more when potential agency problems are coupled with high levels of managerial spending. We find that cash flow rights leverage is particularly important for explaining the cross-sectional variation in CARs associated with subsequent syndicated term loans for firms whose management invests at rates greater than the median firm. The cash flow rights coefficient for high capital expenditure firms is positive and significant at the $1 \%$ level. The coefficient of $0.003(0.3 \%)$ indicates that shareholders of a high-spending firm with cash flow rights leverage at the $90^{\text {th }}$ percentile that issues a subsequent syndicated term loan obtain 1.5 percentage points higher excess returns than those of a firm with no cash flow rights leverage. This result provides further evidence that subsequent term loans serve as an effective governance mechanism in firms with extreme expected agency costs.

24 The testing procedure that resulted in the restricted model followed strict guidelines for covariate analysis. The testing methodology, referred to as the analysis of covariates, is available upon request from the authors. 


\section{Conclusion}

This paper uses a unique dataset incorporating firms with extreme agency problems and detailed information on their types of global debt issuance to construct powerful tests of whether debt capital is able to reduce the impact of agency problems. We provide new evidence that debt creates shareholder value for firms that face potentially high agency costs. We study emerging market firms where the routine use of pyramid ownership structures and, less frequently, superior voting shares by management provides an acute separation of management cash flow rights and control rights.

O ur results indicate that the type of debt that positively impacts shareholder value is the type that closely monitors management. Specifically, we find that the abnormal returns resulting from internationally-syndicated term loans, which provide more comprehensive monitoring than other forms of debt capital, are positively and significantly related to the separation of management ownership and control. These results are especially pronounced within subsequent syndicated term loans and when managers engage in relatively high levels of capital spending. O ur analysis indicates that minority shareholders benefit from intensively monitored debt in a setting where managers are likely to exploit them and where information asymmetry is severe enough that they cannot reasonably infer what managers are doing with a firm's funds. 


\section{References}

Barclay, Michael J., and Clifford W. Smith, Jr., 1995a, The maturity structure of corporate debt, Journal of Finance 50, 609-631.

Booth, Aivazian, Dermirguc-Kunt, and Makismovic, 2001, Capital structures in developing countries, Journal of F inance 56, 87-129.

Campbell, John, 1996, Understanding risk and return, Journal of Political E onomy 104, 298-345.

Cantillo, Miguel and Julian Wright, 2000, How do firms choose their lenders? An empirical investigation, Review of Financial Studies 13, 155-189.

Chaplinsky, Susan and Latha Ramchand, 2000, The Impact of SEC Rule 144A on Corporate D ebt Issuance by Foreign Firms, Working Paper, University of Virginia.

Claessens, Stijn, Simeon Djankov, and Larry H.P. Lang, 2000, The separation of ownership and control in East Asian corporations, Journal of Financial E onomics 58, 81-112.

Claessens, Stijn, Simeon Djankov, Joseph Fan, and Larry H.P. Lang, 2001, Disentangling the incentive and entrenchment effects of large shareholdings, Working Paper, World Bank.

Dermirguc-Kunt and Maksimovic, 1999, Institutions, financial markets, and firm debt maturity, Journal of Financial E conomics 54, 295-336.

Diamond, Douglas, 1984, Financial intermediation and delegated monitoring, Review of E conomic Studies 51, 393-414.

Diamond, D ouglas, 1991a, D ebt Maturity Structure and Liquidity Risk, Q uarterly Journal of E onomics 106, 709-737.

Diamond, D ouglas, 1991b, Monitoring and reputation: The choice between bank loans and directly placed debt, Journal of Political E conomy 99, 689-721.

Domowitz, Ian, Jack Glen, and Ananth Madhavan, 2000, International Evidence on Aggregate Corporate Financing D ecisions, Working Paper, Penn State University.

Fabozzi, Frank, Bond Markets, Analysis and Strategies, 2000, Fourth edition, Prentice-Hall, Inc., Upper Saddle River, New Jersey.

Flannery, Mark, 1986, Asymmetric information and risky debt maturity choice, Journal of Finance 41, 19-37.

Foerster, Stephen, and Andrew Karolyi, 1999, The effects of market segmentation and investor recognition on asset prices: Evidence from foreign stocks listing in the United States, Journal of Finance 54, 981-1013. 
Hart, Oliver, and John Moore, 1995, Debt and seniority: an analysis of the role of hard claims in constraining management, A merican E conomic Review 85, 567-585.

Harvey, Campbell R., and Andrew Roper, 1999, The Asian Bet, in Alison Harwood, Robert E. Litan and Michael Pomerleano, Eds., The Crisis in E merging Financial Markets, Brookings Institution Press, pp. 29-115.

Howcroft, B. and C. Solomon, 1985, Syndicated lending by banks, Banger 0 ccasional Papers in E conomics No. 22, J. Revell, ed. (University of Wales Press).

James, Christopher, 1987, Some evidence on the uniqueness of bank loans, Journal of Finandial E onomics 19, 217-235.

Jensen, Michael C. 1986, Agency costs of free cash flow, corporate finance, and takeovers, A merican E conomic R eview 76, 323-339.

Jensen, Michael C. 1993, The modern industrial revolution, exit, and the failure of internal control systems, Journal of F inanœ 48, 831-880.

Jensen, Michael C. and William H. Meckling, 1976, Theory of the firm: Managerial behavior, agency costs and ownership structure, Journal of F inancial E conomics 3, 305-360.

Johnson, Simon, Rafael La Porta, Florencio Lopez-de-Silanes, and Andrei Shleifer, 2000, Tunnelling, A merican E conomic Review 90, 22-27.

Jung, Kooyul, Yong-Cheol Kim, and René Stulz, 1996, Timing, investment opportunities, managerial discretion, and the security issue decision, Journal of Financial E conomics 42, 159-186.

Karmin, Craig, The W all Street Journal, November 8, 2000.

Kim, Yong Cheol and Rene M. Stulz, 1988, The Eurobond market and corporate financial policy: A test of the clientele hypothesis, Journal of Financial E cnomics, 22, 189-205.

La Porta, Rafael, Florencio Lopez-de-Silanes, Andrei Shleifer, and Robert W. Vishny, 1998, Law and finance, Journal of Political E conomy 106, 1113-1155.

La Porta, Rafael, Florencio Lopez-de-Silanes, Andrei Shleifer, and Robert W. Vishny, 2000, Investor protection and corporate valuation, N BE R W ork ing Paper 7403, 1-44.

Leland, Hayne and David Pyle, 1977, Informational asymmetries, financial structure, and financial intermediation, Journal of F inance 32, 371-387.

Lins, Karl, and Henri Servaes, 1999, International evidence on the value of corporate diversification, Journal of Finance 54, 2215-2239. 
Lins, Karl, 2000, Equity ownership and firm value in emerging markets, Working paper, University of Utah.

London Stock Exchange, April 2000, Listing Eurobonds - Summary listing requirements of the U.K. Listing Authority, www.londonstockexchange.com.

Lummer, Scott and John McConnell, 1989, Further evidence on the bank lending process and the capital-market response to bank loan agreements, Journal of Financial E conomics 25, 99-122.

McConnell, John and Henri Servaes, 1995, Equity ownership and the two faces of debt, Journal of Financial E conomics 39, 131-157.

McConnell, John and Henri Servaes, 1990, Additional evidence on equity ownership and corporate value, Journal of Financial E œnomics 27, 595-612.

Merton, Robert, 1987, A simple model of capital market equilibrium with incomplete information, Journal of Finance 42, 483-510.

Mikkelson, Wayne, and Megan Partch, 1986, Valuation effects of security offerings and the issuance process, Journal of Financial E conomics 15, 31-60.

Miller, Darius, 1999, The market reaction to international cross-listing: evidence from D epositary Receipts, Journal of F inancial E conomics 51, 103-123.

Miller, D arius, and John Puthenpurackal, 2001, The costs, determinants, and wealth effects of public Y ankee bond offerings, Working paper, Indiana University.

Morck, Randall, Andrei Shleifer, and Robert W. Vishny, 1988, Management ownership and market valuation: An empirical analysis, Journal of Financial E conomics 20, 293-315.

Nivatpumin, L and K. Parnsoonthom, June 4, 2001, Fraud bites hard into Asian Sales, Bangkok Post.

Pomerleano, Michael, 1998, The East Asian crisis and corporate finances: the untold microeconomic story, E merging M arkets Q uarterly 2, 14-27.

Rajan, Raghuram, and Luigi Zinagles, 1995, What do we know about capital structure? Some evidence from international data, Journal of Finance 50, 1421-1460.

Ross, Stephen A., 1977, The determination of financial structure: The incentive-signaling approach, Bell Journal of E conomics 8, 23-40.

Scholes, Myron, and Joseph Williams, 1977, Estimating Betas from non-synchronous data, Journal of F inancial E conomics 5, 309-327.

Shleifer, Andrei, and Robert W. Vishny, 1997, A survey of corporate governance, Journal of Finance 52, 737-783. 
Stein, Jeremy, 2001, Agency, information, and corporate investment, in George Constantinides, Milt Harris, and René Stulz eds., $\mathrm{H}$ andbook of the $\mathrm{E}$ conomics of Finanœ, forthcoming.

Stulz, René M., 1990, Managerial discretion and optimal financing policies, Journal of Financial E conomics 26, 3-27.

Titman, Sheridan, and Brett Trueman, 1986, Information quality and the valuation of new issues, Journal of A coounting and E conomics 8, 159-172.

White, Halbert, 1980, A heteroskedasticity-consistent covariance matrix estimator and direct test for heteroskedasticity, E conometrica 48, 817-838.

Z weibel, Jeffrey, 1996, Dynamic capital structure under managerial entrenchment, A merican E conomic Review 86, 1197-1215. 
Figure 1

Charactenistics of Debt Contracts from Various Markets

\begin{tabular}{|c|c|c|c|c|c|c|c|}
\hline \multirow[b]{2}{*}{ Marketplace Characteristics } & \multicolumn{7}{|c|}{ Marketplace of Issue } \\
\hline & $\begin{array}{l}\text { Public } \\
\text { Eurobonds }\end{array}$ & $\begin{array}{l}\text { Public } \\
\text { Domestic } \\
\text { Bonds }\end{array}$ & $\begin{array}{l}\text { Public } \\
\text { U.S. Foreign } \\
\text { Bonds }\end{array}$ & $\begin{array}{l}\text { Private } \\
\text { Domestic } \\
\text { Bonds }\end{array}$ & $\begin{array}{c}\text { Private } \\
\text { Eurobonds }\end{array}$ & $\begin{array}{c}\text { Private } \\
\text { U.S. Foreign } \\
\text { Bonds }\end{array}$ & $\begin{array}{cc}\text { Intemationally } & \text { Internationally } \\
\text { Syndicated Bank } & \begin{array}{c}\text { Syndicated Bank } \\
\text { Credit }\end{array} \\
\text { Agreements } & \text { Temm Loans }\end{array}$ \\
\hline \multirow[t]{2}{*}{ Financial Disclosure Standards } & \multirow{2}{*}{$\begin{array}{l}\text { Unspecified }^{\mathrm{i}} \\
\text { (Local by } \\
\text { Default) }\end{array}$} & \multirow{2}{*}{ Local } & U.S. GAAP ${ }^{\mathrm{ii}}$ & \multirow{2}{*}{ Local } & \multicolumn{3}{|c|}{$\begin{array}{c}\text { Unspecified } \\
\text { (Local by D efault) }\end{array}$} \\
\hline & & & $\begin{array}{l}\text { U.S. Legal } \\
\text { System }^{\text {iv }}\end{array}$ & & $\begin{array}{c}\text { Unspecified }^{\text {iii }} \\
\text { (Local by } \\
\text { D efault) }\end{array}$ & $\begin{array}{l}\text { U.S. Legal } \\
\text { System }^{\text {iv }}\end{array}$ & $\begin{array}{l}\text { Specified in Contract } \mathrm{v}^{\mathrm{v}} \\
\text { (Usually U.S. Legal System) }\end{array}$ \\
\hline Creditor Base & \multicolumn{3}{|c|}{$\begin{array}{c}\text { Diverse } \\
\text { Institutional and Non-institutional Investors }\end{array}$} & \multicolumn{3}{|c|}{$\begin{array}{l}\text { Concentrated } \\
\text { Institutional Buyers }\end{array}$} & $\begin{array}{c}\text { Concentrated } \\
\text { Bank Syndicate Members }\end{array}$ \\
\hline Covenants & Lacking & \multicolumn{3}{|c|}{ Present } & Lacking & \multicolumn{2}{|r|}{ Present } \\
\hline Triggers for Monitoring & $\begin{array}{l}\text { Only in Case of } \\
\text { D efault }\end{array}$ & \multicolumn{3}{|c|}{ Covenant Violations and D efault } & $\begin{array}{l}\text { Only in Case of } \\
\text { D efault }\end{array}$ & \multicolumn{2}{|c|}{ Covenant Violations and D efault } \\
\hline Degree of Monitoring & Weak & & & & & & Strong \\
\hline
\end{tabular}

The London Stock Exchange requires two years of independently audited financial statements prior to listing of Eurobonds. The exchange does not require these statements to be (1) consolidated or (2) conforming to internationally approved accounting standards.

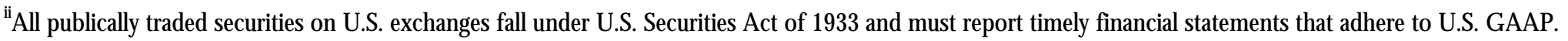

iii According to Fabozzi (2000), most Eurobonds are not regulated by the country whose currency is used to pay creditors. Moreover, since almost all Eurobonds in our sample are U.S. dollar denominated and since the United States does not place restrictions on dollar-denominated issues sold outside its borders, the legal basis for creditors' claims reverts back to the issuer's country of origin.

${ }^{\text {iv }}$ All publicly and privately traded securities traded on U.S. exchanges or over-the-counter in the U.S. are subject to U.S. law.

${ }^{\mathrm{v}}$ According to Howcroft and Solomon (1985) and conversations with syndicate participants, most syndicated agreements stipulate New Y ork State law as the relevant standard for legal interpretation. Moreover, most contracts stipulate that all disagreements will be argued in New Y ork State court.

'D egree of Monitoring' is our assessment of the overall potential for monitoring based on the factors listed in the table. 


\section{Table 1}

\section{Summary statistics for emerging market firms}

Worldscope is the source for all financial data. The potential sample includes all non-financial publicly-traded firms listed on Worldscope at some point during the reporting periods of 1990 through 1997. Values reported are predominantly for fiscal year-end 1996. Tobin's Q is computed as market value of equity plus book assets less the book value of equity all divided by book assets. Cash flow rights leverage is computed as management group control rights divided by management group cash flow rights and includes both pyramid and non-voting equity effects. The values for cash flow rights leverage have been truncated at the 95th percentile. The ratio of short-term debt to total debt is set equal to zero in cases where there is no debt in the capital structure of a firm. Assets are reported in millions of U.S. dollars.

The ownership sample includes all of the firms from Lins (2000) for which cash flow rights leverage can be obtained. The issuance sample includes the firms from the potential sample for which a debt issuance record could be obtained using the Loanware database and the SDC New Issues database. The ownership issuance sample includes those firms with cash flow rights leverage for which a debt issuance record could also be obtained. $* * *, * *$, and $*$ indicate that a statistic from the ownership issuance sample is different from the ownership sample firms that did not issue at the 1, 5, and 10 percent levels, respectively.

\begin{tabular}{|c|c|c|c|c|c|c|c|c|}
\hline & \multicolumn{2}{|c|}{ Potential Sample } & \multicolumn{2}{|c|}{ Ownership Sample } & \multicolumn{2}{|c|}{ Issuance Sample } & \multicolumn{2}{|c|}{$\begin{array}{c}\text { Ownership Issuance } \\
\text { Sample }\end{array}$} \\
\hline & Mean & Median & Mean & Median & Mean & Median & Mean & Median \\
\hline Total assets & 1170 & 322 & 963 & 240 & 1782 & 560 & $1979 * * *$ & $577^{* * *}$ \\
\hline Capex to assets ratio & 0.08 & 0.06 & 0.08 & 0.06 & 0.09 & 0.06 & 0.09 & 0.07 \\
\hline Total debt to assets ratio & 0.30 & 0.30 & 0.28 & 0.27 & 0.36 & 0.34 & $0.34 * * *$ & $0.34 * * *$ \\
\hline Short-term debt to assets ratio & 0.16 & 0.13 & 0.16 & 0.13 & 0.16 & 0.13 & 0.16 & 0.14 \\
\hline Short-term to total debt ratio & 0.55 & 0.54 & 0.60 & 0.62 & 0.48 & 0.43 & $0.50 * * *$ & $0.50 * * *$ \\
\hline Cash flow rights leverage & - & - & 2.09 & 1.00 & - & - & 2.23 & 1.00 \\
\hline Number of observations & \multicolumn{2}{|c|}{1706} & \multicolumn{2}{|c|}{1132} & \multicolumn{2}{|c|}{604} & \multicolumn{2}{|c|}{387} \\
\hline
\end{tabular}


Table 2

Issuing Sample Descriptive Statistics

D escriptive statistics for firms and issues from our issuing sample of 1968 syndicated issues, privately placed debt, and publicly placed debt obtained from the SDC G lobal New Issues database and the Capital D ata Loanware database with non-missing proceeds amount and maturity. O ur sample includes issues from non-financial, publicly traded firms across 19 emerging markets. We require all firms to be identified within the Worldscope database. Firm characteristics are predominantly for fiscal year-end 1996 and are defined in Table 1. Issue size and maturity refer to average total proceeds (US\$ millions) and maturity for a debt category. Panel A provides statistics for debt issues by category and for the firms that issue this debt and includes the entire issuance record (1980-1997) from our debt issuance databases. Panel B lists issue frequency by year and type while Panel C lists the total proceeds of these issues. For brevity, we provide frequency and proceeds information only from 1990-1997 for these latter panels.

Pand A: IssueandFimCharadeistics

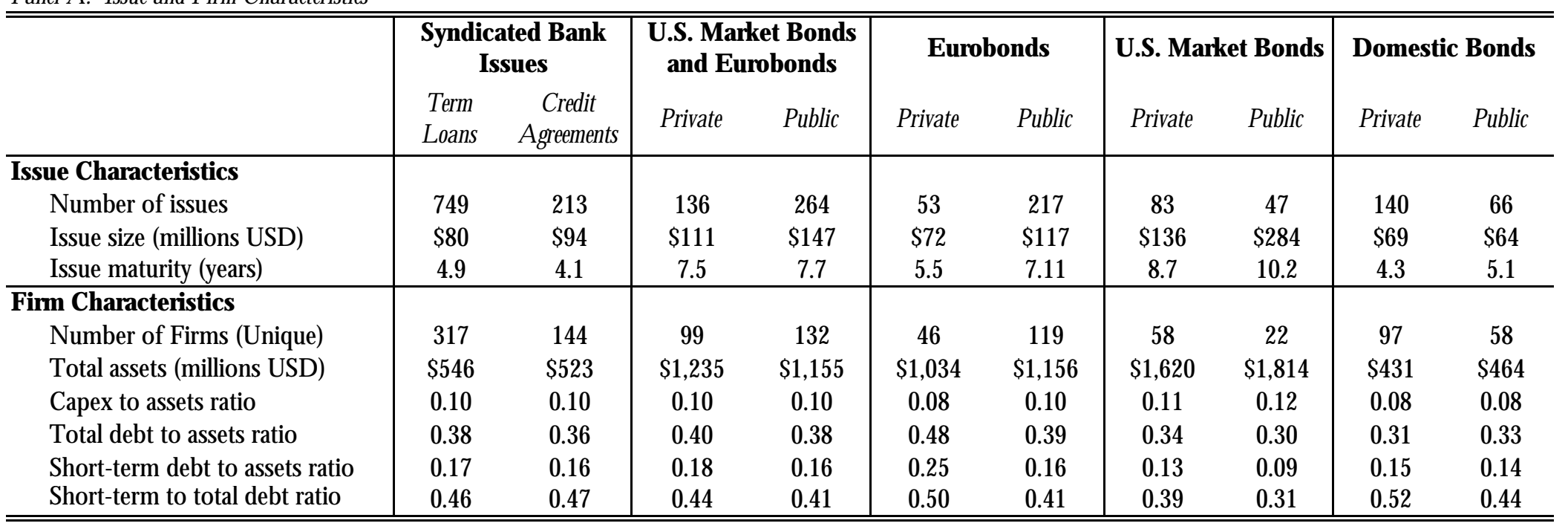


Pand B: Issuefrequenybyyear and markepdace

\begin{tabular}{|c|c|c|c|c|c|c|c|c|c|c|}
\hline \multirow[b]{2}{*}{ Year } & \multicolumn{2}{|c|}{$\begin{array}{c}\text { Syndicated Bank } \\
\text { Issues }\end{array}$} & \multicolumn{2}{|c|}{$\begin{array}{l}\text { U.S. Market Bonds } \\
\text { and Eurobonds }\end{array}$} & \multicolumn{2}{|c|}{ Eurobonds } & \multicolumn{2}{|c|}{ U.S. Market Bonds } & \multicolumn{2}{|c|}{ Domestic Bonds } \\
\hline & $\begin{array}{l}\text { Tem } \\
\text { Lans }\end{array}$ & $\begin{array}{c}\text { Creait } \\
\text { Agements }\end{array}$ & Private & Public & Private & Public & Private & Public & Private & Public \\
\hline 1990 & 11 & 16 & 3 & 7 & 0 & 7 & 3 & 0 & 2 & 0 \\
\hline 1991 & 18 & 13 & 4 & 19 & 4 & 19 & 0 & 0 & 2 & 1 \\
\hline 1992 & 41 & 18 & 13 & 18 & 3 & 15 & 10 & 3 & 10 & 5 \\
\hline 1993 & 57 & 21 & 18 & 45 & 8 & 42 & 10 & 3 & 25 & 8 \\
\hline 1994 & 86 & 31 & 29 & 42 & 14 & 35 & 15 & 7 & 16 & 7 \\
\hline 1995 & 121 & 24 & 21 & 29 & 9 & 26 & 12 & 3 & 16 & 9 \\
\hline 1996 & 165 & 29 & 20 & 49 & 7 & 37 & 13 & 12 & 24 & 7 \\
\hline 1997 & 186 & 33 & 17 & 44 & 4 & 29 & 13 & 15 & 17 & 14 \\
\hline Total & 685 & 185 & 125 & 253 & 49 & 210 & 76 & 43 & 112 & 51 \\
\hline
\end{tabular}

Pand C: Issueproceeds byyear and marketalace

\begin{tabular}{|c|c|c|c|c|c|c|c|c|c|c|}
\hline \multirow[b]{2}{*}{ Year } & \multicolumn{2}{|c|}{$\begin{array}{c}\text { Syndicated Bank } \\
\text { Issues }\end{array}$} & \multicolumn{2}{|c|}{$\begin{array}{l}\text { U.S. Market Bonds } \\
\text { and E urobonds }\end{array}$} & \multicolumn{2}{|c|}{ Eurobonds } & \multicolumn{2}{|c|}{ U.S. Market Bonds } & \multicolumn{2}{|c|}{ Domestic Bonds } \\
\hline & $\begin{array}{l}\text { Tem } \\
\text { Lcans }\end{array}$ & $\begin{array}{c}\text { Creelit } \\
\text { Agreements }\end{array}$ & Private & Public & Private & Public & Private & Public & Private & Public \\
\hline 1990 & $\$ 1,589$ & $\$ 1,794$ & $\$ 365$ & $\$ 380$ & $\$ 0$ & $\$ 380$ & $\$ 365$ & $\$ 0$ & $\$ 32$ & $\$ 0$ \\
\hline 1991 & $\$ 1,080$ & $\$ 1,057$ & $\$ 131$ & $\$ 1,218$ & $\$ 131$ & $\$ 1,218$ & $\$ 0$ & $\$ 0$ & $\$ 26$ & $\$ 12$ \\
\hline 1992 & $\$ 2,547$ & $\$ 1,181$ & $\$ 601$ & $\$ 2,118$ & $\$ 109$ & $\$ 1,322$ & $\$ 492$ & $\$ 796$ & $\$ 232$ & $\$ 412$ \\
\hline 1993 & $\$ 3,596$ & $\$ 1,450$ & $\$ 1,132$ & $\$ 6,579$ & $\$ 406$ & $\$ 5,923$ & $\$ 726$ & $\$ 656$ & $\$ 1,091$ & $\$ 467$ \\
\hline 1994 & $\$ 5,128$ & $\$ 3,070$ & $\$ 2,072$ & $\$ 5,969$ & $\$ 497$ & $\$ 4,010$ & $\$ 1,575$ & $\$ 1,959$ & $\$ 511$ & $\$ 229$ \\
\hline 1995 & $\$ 8,963$ & $\$ 1,458$ & $\$ 2,425$ & $\$ 3,490$ & $\$ 433$ & $\$ 2,642$ & $\$ 1,992$ & $\$ 849$ & $\$ 845$ & $\$ 502$ \\
\hline 1996 & $\$ 11,783$ & $\$ 2,196$ & $\$ 2,706$ & $\$ 7,440$ & $\$ 1,121$ & $\$ 3,847$ & $\$ 1,585$ & $\$ 3,594$ & $\$ 2,097$ & $\$ 511$ \\
\hline 1997 & $\$ 15,754$ & $\$ 4,749$ & $\$ 3,738$ & $\$ 9,693$ & $\$ 479$ & $\$ 5,021$ & $\$ 3,259$ & $\$ 4,672$ & $\$ 1,306$ & $\$ 1,038$ \\
\hline Total & $\$ 50,439$ & $\$ 16,956$ & $\$ 13,170$ & $\$ 36,887$ & $\$ 3,177$ & $\$ 24,361$ & $\$ 9,993$ & $\$ 12,525$ & $\$ 6,141$ & $\$ 3,171$ \\
\hline
\end{tabular}


Table 3

\section{The effect of leverage and ownership structure on firm value in emerging markets}

Cross-sectional regressions use variables defined in Table 1 and are estimated using the ownership sample. Tobin's Q is the dependent variable and has been winsorized at the 1st and 99th percentiles. We report OLS parameter estimates and robust standard errors following White (1980). ***, **, and $*$ indicate significance at the 1\%,5\%, and 10\% levels. All regressions include unreported country-specific intercepts and industry-specific intercepts (based on Campbell (1996) industry groupings). The Hausman (1978) specification test fails to reject that the estimates of the fixed effects estimator are statistically different from those of the random effects model (result not reported). Models (1) and (2) report regression specifications for the full ownership sample. Models (3), (4), (5), and (6) report regression specifications for firms that have above- or below-median ratios fo capital expenditures to total assets.

\begin{tabular}{|c|c|c|c|c|c|c|}
\hline \multirow[b]{2}{*}{ Independent Variable is Q } & \multicolumn{2}{|c|}{ O wnership Sample } & \multicolumn{2}{|c|}{$\begin{array}{l}\text { Above-median } \\
\text { capex to assets }\end{array}$} & \multicolumn{2}{|c|}{$\begin{array}{l}\text { Below-median } \\
\text { capex to assets }\end{array}$} \\
\hline & $(1)$ & $(2)$ & (3) & $(4)$ & (5) & (6) \\
\hline Intercept & $\begin{array}{l}1.960 \text { *** } \\
(0.303)\end{array}$ & $\begin{array}{l}2.099 * * * \\
(0.308)\end{array}$ & $\begin{array}{l}1.661 \text { *** } \\
(0.408)\end{array}$ & $\begin{array}{l}2.220 \text { *** } \\
(0.520)\end{array}$ & $\begin{array}{l}2.839 \text { *** } \\
(0.482)\end{array}$ & $\begin{array}{l}4.397 \text { *** } \\
(1.031)\end{array}$ \\
\hline Log of assets & $\begin{array}{l}-0.055 * * * \\
(0.022)\end{array}$ & $\begin{array}{l}-0.065 * * * \\
(0.023)\end{array}$ & $\begin{array}{l}-0.021 \\
(0.030)\end{array}$ & $\begin{array}{l}-0.033 \\
(0.031)\end{array}$ & $\begin{array}{l}-0.117 \text { *** } \\
(0.033)\end{array}$ & $\begin{array}{l}-0.126 \text { *** } \\
(0.033)\end{array}$ \\
\hline Capital expenditures to assets & $\begin{array}{r}0.484 \\
(0.311)\end{array}$ & $\begin{array}{r}0.414 \\
(0.306)\end{array}$ & $\begin{array}{r}0.365 \\
(0.426)\end{array}$ & $\begin{array}{r}0.356 \\
(0.422)\end{array}$ & $\begin{array}{r}0.957 \\
(2.119)\end{array}$ & $\begin{array}{r}0.764 \\
(2.158)\end{array}$ \\
\hline D ebt to assets & $\begin{array}{l}-1.072 * * * \\
(0.194)\end{array}$ & & $\begin{array}{l}-1.477 \text { *** } \\
(0.281)\end{array}$ & & $\begin{array}{l}-0.827 \text { *** } \\
(0.279)\end{array}$ & \\
\hline Cash flow rights leverage & $\begin{array}{l}-0.048 * * * \\
(0.014)\end{array}$ & $\begin{array}{l}-0.050 * * * \\
(0.014)\end{array}$ & $\begin{array}{l}-0.054 \text { *** } \\
(0.020)\end{array}$ & $\begin{array}{l}-0.056 \text { *** } \\
(0.021)\end{array}$ & $\begin{array}{l}-0.040 * * \\
(0.019)\end{array}$ & $\begin{array}{l}-0.039 \text { ** } \\
(0.019)\end{array}$ \\
\hline $\mathrm{CF}$ rights leverage $\mathrm{x}$ debt/ assets & $\begin{array}{l}0.094 * * * \\
0.035\end{array}$ & & $\begin{array}{l}0.114 \text { ** } \\
(0.049)\end{array}$ & & $\begin{array}{r}0.058 \\
(0.055)\end{array}$ & \\
\hline Short-term debt to assets & & $\begin{array}{l}-1.410 * * * \\
(0.249)\end{array}$ & & $\begin{array}{l}-1.997 \text { *** } \\
(0.339)\end{array}$ & & $\begin{array}{l}-1.018 \text { *** } \\
(0.362)\end{array}$ \\
\hline Long-term debt to assets & & $\begin{array}{l}-0.681 \text { *** } \\
(0.243)\end{array}$ & & $\begin{array}{l}-1.034 \text { *** } \\
(0.355)\end{array}$ & & $\begin{array}{l}-0.494 \\
(0.325)\end{array}$ \\
\hline CF rights leverage $\mathrm{x}$ ST debt/ assets & & $\begin{array}{l}0.123 \text { *** } \\
(0.050)\end{array}$ & & $\begin{array}{l}0.157 \text { ** } \\
(0.074)\end{array}$ & & $\begin{array}{r}0.047 \\
(0.073)\end{array}$ \\
\hline CF rights leverage $\mathrm{x} L T$ debt/ assets & & $\begin{array}{r}0.066 \\
(0.054) \\
\end{array}$ & & $\begin{array}{r}0.084 \\
(0.087) \\
\end{array}$ & & $\begin{array}{r}0.055 \\
(0.065) \\
\end{array}$ \\
\hline Number of observations & 1131 & 1131 & 566 & 566 & 565 & 565 \\
\hline R-Squared Adjusted & 0.29 & 0.29 & 0.32 & 0.32 & 0.28 & 0.28 \\
\hline F-Statistic & 15.11 & 14.41 & 9.33 & 7.86 & 8.1 & 9.26 \\
\hline P-Value & 0.00 & 0.00 & 0.00 & 0.00 & 0.00 & 0.00 \\
\hline
\end{tabular}


Table 4

Subsample Tests with Issuing Fims

Q is the dependent variable and has been winsorized at the 1st and 99th percentiles. Variables are defined in Table 1. We report O LS parameter estimates and robust standard errors following White (1980). ${ }^{* *}$, **, and * indicate significance at the $1 \%, 5 \%$, and $10 \%$ levels. All regressions include unreported country-specific intercepts and industry-specific intercepts (based on Campbell (1996) industry groupings). The Hausman (1978) specification test fails to reject the hypothesis that the estimates of the fixed effects estimator are statistically different from those of the random effects model (result not reported).

Models (1) and (2) are estimated on the ownership issuance sample which includes those firms for which cash flow rights leverage could be computed that also had a debt issuance record on either the Loanware database or the SDC New Issues database. Models (3) and (4) are estimated on the portion of the ownership sample for which no debt issuance record could be obtained. $\wedge$ ^ $\wedge$, and $\wedge$ indicate significance at the $1 \%, 5 \%$, and $10 \%$ levels in the difference between the coefficients across the sub-samples.

\begin{tabular}{|c|c|c|c|c|c|c|}
\hline \multirow[b]{2}{*}{ Independent Variable is Q } & \multicolumn{2}{|c|}{ O wnership Issuance Sample } & \multicolumn{2}{|c|}{$\begin{array}{l}\text { O wnership Non-Issuance } \\
\text { Sample }\end{array}$} & \multicolumn{2}{|c|}{$\begin{array}{c}\text { Differences in coefficients } \\
\text { across sub-samples }\end{array}$} \\
\hline & $(1)$ & (2) & (3) & (4) & $(1)-(3)$ & (2) - (4) \\
\hline Intercept & $\begin{array}{l}1.380 * * \\
0.615\end{array}$ & $\begin{array}{l}1.599 * * * \\
0.632\end{array}$ & $\begin{array}{l}3.900 * * * \\
0.608\end{array}$ & $\begin{array}{l}3.933 \text { *** } \\
0.610\end{array}$ & -2.519 & -2.334 \\
\hline Log of assets & $\begin{array}{r}-0.018 \\
0.038\end{array}$ & $\begin{array}{r}-0.029 \\
0.038\end{array}$ & $\begin{array}{l}-0.102 * * * \\
0.032\end{array}$ & $\begin{array}{l}-0.104 * * * \\
0.033\end{array}$ & 0.084 & 0.076 \\
\hline Capital expenditures to assets & $\begin{array}{l}0.867 * * \\
0.392\end{array}$ & $\begin{array}{l}0.555 \\
0.409\end{array}$ & $\begin{array}{l}0.235 \\
0.417\end{array}$ & $\begin{array}{l}0.212 \\
0.417\end{array}$ & 0.632 & 0.343 \\
\hline Debt to assets & $\begin{array}{l}-1.056 * * * \\
0.344\end{array}$ & & $\begin{array}{l}-1.168 * * * \\
0.251\end{array}$ & & $0.112 \leadsto$ & \\
\hline Short-term debt to assets & & $\begin{array}{l}-1.588 * * * \\
0.385\end{array}$ & & $\begin{array}{l}-1.170 * * * \\
0.323\end{array}$ & & -0.417 \\
\hline Long-term debt to assets & & $\begin{array}{r}-0.609 \\
0.424\end{array}$ & & $\begin{array}{l}-1.161 * * * \\
0.362\end{array}$ & & $0.552^{\wedge}$ \\
\hline Cash flow rights leverage & $\begin{array}{r}-0.026 \\
0.031\end{array}$ & $\begin{array}{r}-0.030 \\
0.033\end{array}$ & $\begin{array}{l}-0.052 * * * \\
0.016\end{array}$ & $\begin{array}{l}-0.050 * * * \\
0.016\end{array}$ & 0.026 & 0.020 \\
\hline CF rights leverage $\mathrm{x}$ debt/ assets & $\begin{array}{l}0.029 \\
0.070\end{array}$ & & $\begin{array}{l}0.145^{* * *} \\
0.047\end{array}$ & & -0.116 & \\
\hline $\mathrm{CF}$ rights leverage $\mathrm{x} \mathrm{ST}$ debt/ assets & & $\begin{array}{l}0.045 \\
0.077\end{array}$ & & $\begin{array}{l}0.098 \\
0.066\end{array}$ & & -0.054 \\
\hline CF rights leverage $\mathrm{x}$ LT debt/ assets & & $\begin{array}{l}0.021 \\
0.105\end{array}$ & & $\begin{array}{l}0.216 \text { *** } \\
0.082\end{array}$ & & -0.195 \\
\hline $\begin{array}{l}\text { Number of observations } \\
\text { R-squared } \\
\text { F-Statistic } \\
\text { P-Value }\end{array}$ & $\begin{array}{l}386 \\
0.26 \\
5.32 \\
0.00\end{array}$ & $\begin{array}{l}386 \\
0.27 \\
5.21 \\
0.00\end{array}$ & $\begin{array}{c}746 \\
0.30 \\
10.52 \\
0.00\end{array}$ & $\begin{array}{l}746 \\
0.30 \\
9.89 \\
0.00\end{array}$ & & \\
\hline
\end{tabular}


Table 5

\section{Event study abnomal returns by market type}

Average cumulative abnormal returns (CAR) are reported for a six-day event window which includes one trading day prior to issue, the issue date, and the subsequent four trading days. The sample includes firms from the issuing sample for which daily stock returns could be obtained and has multiple issues for some firms. A normal return model using Scholes-Williams (1977) betas is estimated using 120 trading days prior to issue date, excluding a 20 day event window centered around the issue date. $* * *, * *$, and * indicate significance at the $1 \%$, $5 \%$, and $10 \%$ levels.

\begin{tabular}{|c|c|c|c|c|c|c|c|}
\hline Issue Type & $\begin{array}{c}\text { Sample } \\
\text { Size }\end{array}$ & \multicolumn{2}{|c|}{ CAR } & Z-Statistic & $\begin{array}{l}\text { Percent } \\
\text { Positive }\end{array}$ & \multicolumn{2}{|c|}{$\begin{array}{c}\text { Generalized } \\
\text { Sign Z } \\
\end{array}$} \\
\hline Syndicated TemLans & 729 & $1.34 \%$ & $* * *$ & 3.80 & 0.56 & 3.69 & *** \\
\hline Syndicateed CreeditAgeements & 223 & $-0.11 \%$ & & -0.61 & 0.48 & -0.18 & \\
\hline US Market andEurdbandsPublic & 129 & $-0.37 \%$ & & -0.58 & 0.49 & 0.17 & \\
\hline US Market and EurdbondsPrivate & 245 & $-0.18 \%$ & & 0.68 & 0.55 & 1.99 & $* *$ \\
\hline EurdbandsPublic & 201 & $-0.14 \%$ & & 0.76 & 0.54 & 1.79 & $*$ \\
\hline EurdbandsPrivate & 48 & $-0.84 \%$ & & -0.56 & 0.50 & 0.39 & \\
\hline U.S. Marke BandsPublic & 44 & $-0.33 \%$ & & -0.01 & 0.57 & 0.88 & \\
\hline U.S. Marke BandsPrivate & 81 & $-0.08 \%$ & & -0.29 & 0.48 & -0.07 & \\
\hline DomesticPublicBands & 61 & $-0.34 \%$ & & -0.73 & 0.51 & 0.60 & \\
\hline DomesticPrivateBonds & 113 & $-1.00 \%$ & & -1.57 & 0.46 & -0.20 & \\
\hline
\end{tabular}


Table 6

Abnormal returns for first and subsequent intemational issues

Average cumulative abnormal returns (CAR) are reported for a six-day event window which includes one trading day prior to issue, the issue date, and the subsequent four trading days. A normal return model with Scholes-Williams (1977) betas is estimated using 120 trading days prior to issue date, excluding a 20 day event window centered around the issue date. The sample includes firms from the issuing sample for which daily stock returns could be obtained and has multiple issues for some firms. Within each firm, an international offering counter segregates a firm's initial international offering (across all international markets) from all subsequent international offers. Within each firm, an issue level counter segregates the initial debt placement in a certain market from all secondary offerings in the same market.

The table reports CARs for the inital international issue across issue types (international offering counter equal to initial) as well as the CARs for secondary offerings across issue types (issue level counter not equal to initial placement). ***, **, and * indicate significance at the $1 \%, 5 \%$, and $10 \%$ levels. The two right hand columns report the difference in CARs between inital and subseqent offerings and a t-test of this difference.

\begin{tabular}{|c|c|c|c|c|c|c|c|}
\hline & $\begin{array}{l}\text { Sample } \\
\text { Size }\end{array}$ & CAR & $\begin{array}{c}\text { Z- } \\
\text { Statistic }\end{array}$ & $\begin{array}{l}\text { Percent } \\
\text { Positive }\end{array}$ & $\begin{array}{l}\text { Generalized } \\
\text { Sign Z }\end{array}$ & $\begin{array}{l}\text { Difference } \\
\text { between } \\
\text { Subsequent } \\
\text { and Initial } \\
\text { Offerings }\end{array}$ & $\begin{array}{c}\text { T- } \\
\text { Statistic }\end{array}$ \\
\hline \multicolumn{8}{|c|}{ Panel A: Abnormal Returns for Initial Intemational Issue by Issue Type } \\
\hline Syndicated TemLcans & 182 & $-0.81 \% * *$ & 2.00 & $45 \%$ & -1.05 & $1.33 \% * * *$ & 3.75 \\
\hline Syndicated CreeditAgeements & 80 & $-0.05 \%$ & 0.18 & $53 \%$ & 0.79 & $-0.73 \%$ & -1.13 \\
\hline U.S. Marke andEurdbondsPublic & 71 & $0.92 \% *$ & 1.91 & $56 \%$ & 1.26 & $-2.70 \% * * *$ & -5.35 \\
\hline U.S. Marke andEurdbondsPrivate & 41 & $0.04 \%$ & 0.45 & $56 \%$ & 1.23 & $-0.98 \%$ & -1.36 \\
\hline EurdbandsPublic & 65 & $0.83 \%$ & 1.52 & $55 \%$ & 1.06 & $-2.69 \% * * *$ & -4.87 \\
\hline EurdbondsPrivate & 22 & $-0.01 \%$ & 0.70 & $55 \%$ & 0.82 & $-1.84 \%$ & -1.36 \\
\hline U.S. Marke BandsPublic & 6 & $1.90 \%$ & 1.56 & $67 \%$ & 0.83 & $-3.73 \% * *$ & -2.28 \\
\hline U.S. Marke BandsPublic & 19 & $0.08 \%$ & -0.10 & $58 \%$ & 0.93 & $-0.63 \%$ & -0.74 \\
\hline \multicolumn{8}{|c|}{ Panel B: Abnormal Retums for Subsequent Issues by Issue Type } \\
\hline Syndicated TemLLcans & 483 & $1.09 \% * * *$ & 4.30 & $61 \%$ & $5.17 * * *$ & $1.11 \% * * *$ & 3.59 \\
\hline Syndicated CreeditAgreements & 136 & $-0.37 \%$ & -1.35 & $44 \%$ & -0.95 & $-0.83 \%$ & -1.32 \\
\hline U.S. Marke andEurdbondsPublic & 136 & $-0.26 \%$ & 0.53 & $56 \%$ & $1.74 *$ & $-1.22 \% * *$ & -2.54 \\
\hline U.S. Marke and EurdbondsPrivate & 46 & $-1.01 \%$ & 1.57 & $46 \%$ & -0.32 & $-1.07 \%$ & -1.62 \\
\hline EurdbandsPublic & 109 & $-0.17 \%$ & 0.65 & $56 \%$ & $1.68 *$ & $-1.53 \% * * *$ & -2.77 \\
\hline EurdbondsPrivate & 20 & $-2.58 \% *$ & -1.98 & $40 \%$ & -0.60 & $-1.65 \%$ & -1.24 \\
\hline U.S. Marke BandsPublic & 28 & $-0.58 \%$ & -0.10 & $54 \%$ & 0.34 & $-0.11 \%$ & -0.12 \\
\hline U.S. Marke BondsPrivate & 26 & $0.20 \%$ & -0.36 & $50 \%$ & 0.08 & $-0.71 \%$ & -0.94 \\
\hline
\end{tabular}


Table 7

Abnormal retums for selected issues based on firm attributes

Average cumulative abnormal returns (CAR) are reported for a six-day event window which includes one trading day prior to issue, the issue date, and the subsequent four trading days. A normal return model with Scholes-Williams (1977) betas is estimated using 120 trading days prior to issue date, excluding a 20 day event window centered around the issue date. The sample includes firms from the issuing sample for which daily stock returns could be obtained and has multiple issues for some firms. All firms within the Potential Sample (see Table 1) are sorted according to their firm-specific time-series mean of each attribute and placed into Low (below median) or High (above median) groups.

Two counters are used for construction of the table. In Panel A, an international offering counter segregates, within each firm, the initial international offering across all internatinal markets from all subsequent international offers. In Panel B, an issue level counter segregates, within each firm, the initial placement in a certain market from all secondary offering in the same market. Panel A reports CARs and key statistics for initial public U.S. market bonds and Eurobond offerings (initial international counter $=1$ ) across the various firm attribute groups. Panel B reports CARs and key statistics relating to subsequent syndicated term loan offerings (subsequent issue counter $=1$ ) across the various sorts. $* * *, * *$, and $*$ indicate significance at the $1 \%, 5 \%$, and $10 \%$ levels. The rightmost two columns report the difference in CARs between the High and Low groups and a t-test of this difference.

\begin{tabular}{|c|c|c|c|c|c|c|c|}
\hline & $\begin{array}{l}\text { Sample } \\
\text { Size }\end{array}$ & CAR & Z-Statistic & $\begin{array}{l}\text { Percent } \\
\text { Positive }\end{array}$ & $\begin{array}{l}\text { Generalized } \\
\text { Sign Z }\end{array}$ & $\begin{array}{c}\text { Difference } \\
\text { between } \\
\text { High/ Low } \\
\text { Sorts } \\
\end{array}$ & T-Statistic \\
\hline \multicolumn{8}{|c|}{ Panel A: Abnormal Retums for Initial Public U.S. Market and E urobonds } \\
\hline Lowsize(assets) fims & 8 & $-1.05 \%$ & 0.52 & $38 \%$ & -0.42 & $2.23 \% * *$ & 2.09 \\
\hline High size(assts) fims & 63 & $1.18 \% * *$ & 2.23 & $59 \%$ & 1.49 & & \\
\hline Lowddt-toassetsfims & 20 & $3.17 \% * *$ & 2.54 & $55 \%$ & 0.55 & $-3.05 \%$ & 0.82 \\
\hline High datt-toasstsfims & 51 & $0.12 \%$ & 0.70 & $57 \%$ & 1.14 & & \\
\hline Lowcapex-toassts fims & 29 & $0.39 \%$ & 0.23 & $48 \%$ & 0.01 & $0.91 \% * * *$ & 4.07 \\
\hline Highcapex-toassts fims & 42 & $1.30 \% * *$ & 2.28 & $62 \%$ & 1.63 & & \\
\hline Lowshat-temtotatal dett fims & 55 & $0.75 \% *$ & 1.77 & $53 \%$ & 0.57 & $0.82 \% *$ & -1.91 \\
\hline High shat-termtotctal dett fims & 16 & $1.57 \%$ & 0.75 & $69 \%$ & 1.59 & & \\
\hline Lowcash flowrightsleveragefims & 27 & $0.38 \%$ & 0.45 & $59 \%$ & 1.04 & $-0.63 \%$ & 0.33 \\
\hline High cashflowrightsleveragefims & 14 & $-0.25 \%$ & 0.13 & $50 \%$ & 0.02 & & \\
\hline \multicolumn{8}{|c|}{ Panel B: Abnormal Returns for Subsequent Syndicated Term Loan Offerings } \\
\hline Lowsize(assets) fims & 45 & $-0.68 \%$ & -0.52 & $44 \%$ & -0.60 & $1.96 \%$ & 1.07 \\
\hline High size(assets) fims & 438 & $1.28 \% * * *$ & 4.68 & $63 \%$ & $5.62 * * *$ & & \\
\hline Lowddt-toassets fims & 73 & $0.06 \%$ & 0.53 & $59 \%$ & $1.67 *$ & $1.20 \%$ & -0.02 \\
\hline High dedt-toassetsfimms & 410 & $1.26 \% * * *$ & 4.43 & $61 \%$ & $4.90 * * *$ & & \\
\hline Lowcapex-toassts fims & 114 & $0.66 \%$ & 0.96 & $59 \%$ & $2.22 * *$ & $0.56 \%$ & 0.98 \\
\hline Highcapex-toassts fims & 369 & $1.22 \% * * *$ & 4.39 & $62 \%$ & $4.67 * * *$ & & \\
\hline Lowshat-temtotalal dett fims & 390 & $1.22 \% * * *$ & 4.40 & $62 \%$ & $5.14 * * *$ & $-0.66 \%$ & -0.46 \\
\hline High shat-termtotctal dett fims & 95 & $0.56 \%$ & 0.82 & $55 \%$ & 1.02 & & \\
\hline Lowcash flowrightsleveragefims & 191 & $1.33 \% * * *$ & 2.87 & $59 \%$ & $2.55 * *$ & $0.15 \% * * *$ & 2.72 \\
\hline High cashflowrightsleveragefims & 68 & $1.48 \% * * *$ & 3.10 & $65 \%$ & $2.90 * * *$ & & \\
\hline
\end{tabular}


Table 8

\section{Multivariate Analysis of Cumulative Abnormal Returns by Type of Debt Issue}

The independent variable is the average cumulative abnormal returns (CAR) from a six-day event window which includes one trading day prior to issue, the issue date, and the subsequent four trading days. O ur basic regression model is estimated in eight debt offering subsamples which are described in the headings below. D ependent variables are described in Table 1. All regressions include unreported country dummies (fixed effects). We report GLS parameter estimates using weights that are proportional to the variance of the estimated market model. ***,**, $*$, indicate significance at the $1 \%, 5 \%$, and $10 \%$ levels.

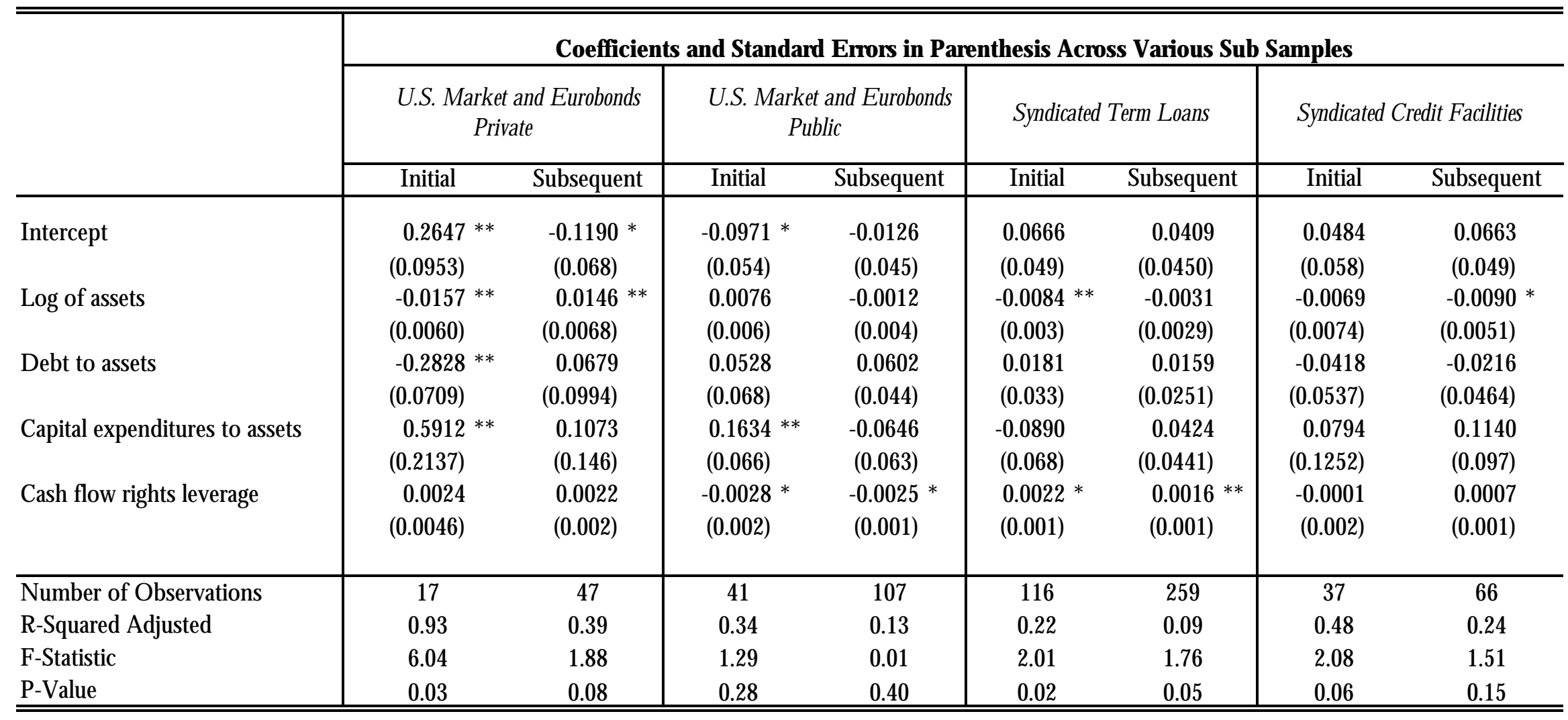


Table 9

Multivariate Cross-Sectional Regressions for Pooled Cumulative Abnormal Returns

The independent variable is the average cumulative abnormal returns (CAR) from a six-day event window which includes one trading day prior to issue, the issue date, and the subsequent four trading days. We report G LS parameter estimates using weights that are proportional to the variance of the estimated market model.The two models present pooled cross-sectional analysis across the sub-samples investigated in Table 8 (690 observations). Model (1) has CARs regressed on: fixed effects for issue market, timing, and firm country of domicile (coefficients not reported); firm size; firm leverage; and capital expenditure and cash flow rights leverage slopes that vary across debt market and issue type. In Model (2), the capital expenditure and cash flow rights leverage slopes are also allowed to vary across firms with above- and below-median ratios of capital expenditures to assets. For the sake of brevity, we report only the coefficients on the high and low capital expenditure dummy variable interactions with cash flow rights leverage. $* * * * *, *$ indicate significance at the $1 \%, 5 \%$, and $10 \%$ levels.

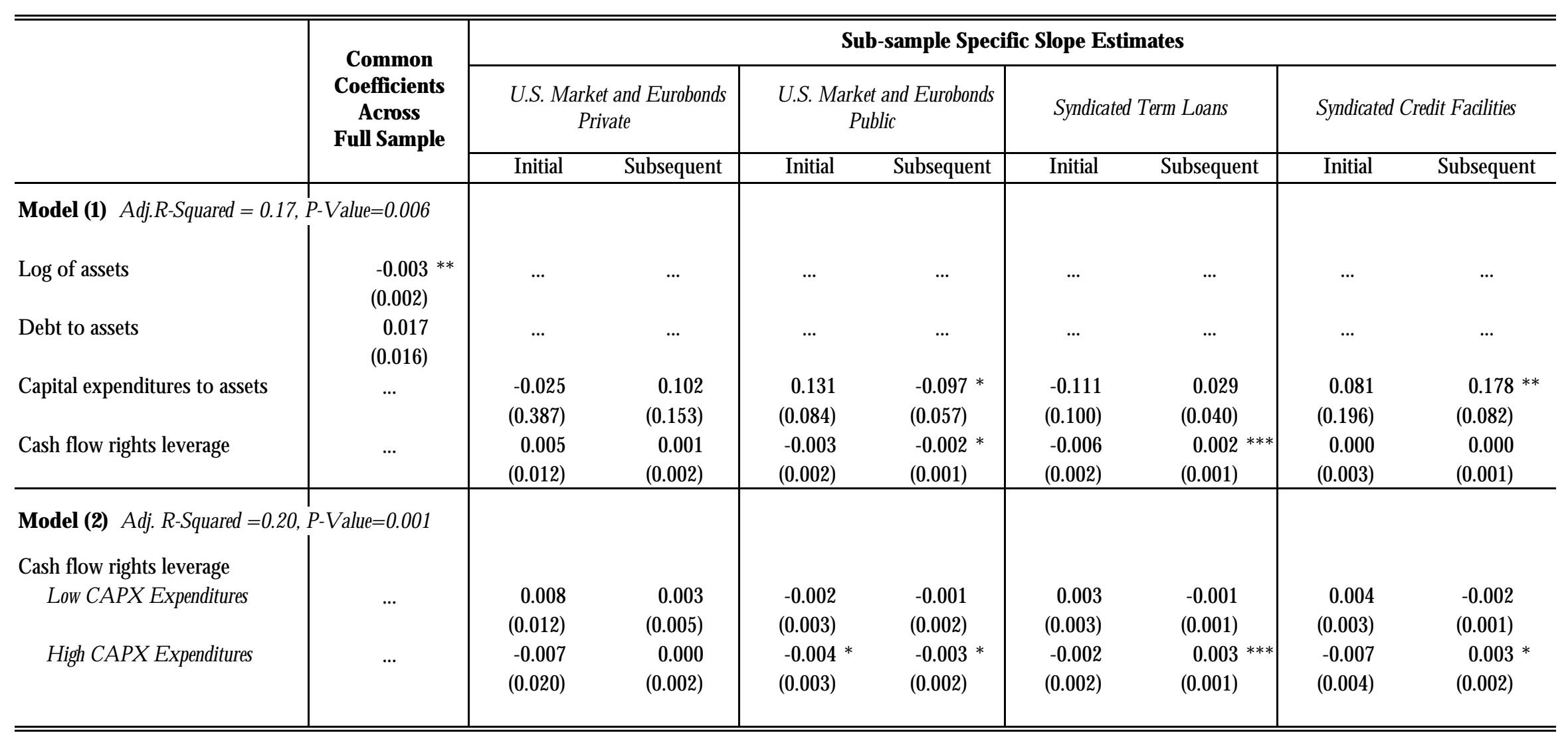

